\title{
Unstable Narrative Voices and the Irrelevance of Fiction in The Famished Road
}

\section{Kerry-Jane Wallart}

\section{(2) OpenEdition \\ 1 Journals}

Electronic version

URL: https://journals.openedition.org/ces/5367

DOI: $10.4000 /$ ces.5367

ISSN: 2534-6695

\section{Publisher}

SEPC (Société d'études des pays du Commonwealth)

\section{Printed version}

Date of publication: 1 April 2013

Number of pages: 91-100

ISSN: 2270-0633

\section{Electronic reference}

Kerry-Jane Wallart, "Unstable Narrative Voices and the Irrelevance of Fiction in The Famished Road", Commonwealth Essays and Studies [Online], 35.2 | 2013, Online since 17 April 2021, connection on 23 July 2021. URL: http://journals.openedition.org/ces/5367 ; DOI: https://doi.org/10.4000/ces.5367

\section{(c) $($ †) $\ominus$}

Commonwealth Essays and Studies is licensed under a Licence Creative Commons Attribution - Pas d'Utilisation Commerciale - Pas de Modification 4.0 International. 


\section{Unstable Narrative Voices and the Irrelevance of Fiction in The Famished Road}

This paper scrutinizes the position of the narrator as one of superior knowledge as much as of great and largely ironic ignorance. In both cases the narration lays the emphasis on the necessity for Azaro to interpret the world rather than on a creative process. The device is thus realistic rather than magic realist but the stark contrast resulting from the choice of a first person narration provokes readerly puzzlement and I contend that it is to be solved by a foregrounding of interrogation rather than of certainty.

"A dream can be the highest point of a life" (574); the last sentence of the novel delivers an aphorism, a piece of wisdom in a nutshell, a word to keep for a raincheck. It is a kernel of truth whose relevance is that of life, not fiction, as the end of the sentence intimates. Aphorisms abound in The Famished Road (e.g., "One world contains glimpses of others" [11]) and the adjective "gnomic" appears here and there, even though it is yoked with nouns that are unexpected ("gnomic chants on the untrodden roads," [134] "a beautiful cat with gnomic eyes" [360]). Such emphasis on what can be learnt from fiction recalls the double West African tradition of the Onitsha market literature and the Pentecostal publications. Stephanie Newell (101-12) explains that the former, named after the Nigerian Igbo town where these books were all published, catered to a young, educated and mostly male middle-class, invading the market with didactic yet sentimental novels about urban young people discovering the world of love and marriage. Some patterns from this hugely popular trend from the 1950s and 1960s can be found in The Famished Road. ${ }^{1}$ More than upon the plot, I suggest that Okri draws upon the didactic dimension of these novels which were taken by readers as self-help guides (see Achebe 27-8). Still according to Newell (112-9), the other major popular form of reading in post-Independence Nigeria is that of Christian pamphlets:

Like the authors of market literature in the 1950s and 1960s, contemporary Christian authors acknowledge that readers expect to receive knowledge that can be applied directly to their own life situations, and their pamphlets offer explanations for failure and unhappiness, giving divine and practical solutions to problems occurring in everyday life. (115)

Newell focuses not only on the actual importance of such a tradition in Nigerian literary culture but also on the fact that ever since the publication of Achebe's Things Fall Apart (1958) and its clear-cut opposition of Christian and African values, "the vast local consumption of Christian literature in West Africa is often treated as an embarrassing secret, rarely mentioned in literary histories of the region" (113); it seems enlightening to read The Famished Road with such messianic texts at the back of one's mind. In both the Onitsha novel or the Pentecostal pamphlet the author claims a full and superior authority; (s)he steps aside from the world of fiction at very regular intervals in order to sum up the situation with a precept that much resembles in form, if not in content, the ones the reader will find scattered around in the pages of The Famished Road. Yet, such

1. A case in point being a stock scene in Onitsha literature where a young man follows the woman he loves into the forest only to discover that she is a half-witch and turns into a monster once in the wilderness - a scene that is recast under various forms by Ben Okri, not least in the third chapter of Book One. 
aphorisms are problematic if not altogether ironic. One might think of the one which is yielded by the rats ${ }^{2}$ to which Azaro listens at night on the advice of his father, in a passage that is strategically placed at the very end of the first Book in the novel. The dictum is certainly perplexing ("the world is tougher than fire or steel" [84-5]), not least because of the adjective ("tough") that seems entirely inappropriate when referring to fire. As in the case of "gnomic," an inability to make sense of the world is disguised under a tone of assurance but conveyed through linguistic oddity. In the passage concerned with the wisdom of rats there follows another aphorism, a true but rather trite one, concerning the fact that unlike men, rats speak only one language. Azaro then tries to communicate with them, thereby betraying his own childish naïveté and inexperience. Such inexperience is foregrounded again when Azaro recalls the episode and uses it as a supposedly conclusive argument in a dialogue with the photographer: "'It's a hard life,' he said. / 'That's what the rats know about life" (306). This article wishes to interrogate the hermeneutic instability of such a narrative voice, poised as it is between omniscience and, on the other hand, the limitations of a first person narrator who enjoys a limited perspective and is, into the bargain, too young to understand much of what he reports. The volatility in perspective has often been commented on in discussions of the novel ("Okri's authorial viewpoint is elusive," e.g., in Cooper 69) and I argue that it is linked to the absence of a clear definition, or of a definite conception, of the role of the narrator. This implies that Azaro himself is straddling the fence between knowledge and ignorance. This departs from the interpretation according to which Azaro is fully naive and the reader is "continually socialized into a narrative situation that combines the gnomic and proverbial affirmations of communal world-views with the growing and provisional perceptions of a limited narrative perspective" (Quayson 126). The former "proverbial affirmations" are sometimes voiced by Azaro himself, while a "limited narrative perspective" may be yielded by Mum, Dad or even Madame Koto, all of whom vie for a position as narrator that shifts and fluctuates at least as much as the road evoked in the title.

Azaro's position is indeed a privileged one due to his status as an abiku. He sees what others do not and is aware of things and people that even Madame Koto, with all her supernatural powers, fails to perceive (“"I didn't see anybody" [92]). His experience is thus diffracted as through a prism, expanded and enriched thanks to an abolition of the traditional boundaries between past and future as well as self and others:

When I was very young I had a clear memory of my life stretching to other lives. There were no distinctions. Sometimes I seemed to be living several lives at once. One lifetime flowed into the others and all of them flowed into my childhood. (8)

In this and other passages (e.g., the description of the road at the bottom of page 132, or Azaro's reverie on pages 255-6), the preposition "into" appears as structurally seminal and pivotal, outlining as it does some interiority which is also a space of metamorphosis. It lets the reader believe that the perception to which we have access in the novel is extraordinarily powerful, placing The Famished Road on the side of texts whose

2. An important element in the prolific and often symbolic bestiary of the novel, the rats are mentioned as an authority again on page 306 but are also often associated, much less paradoxically so, with poverty ("muttering to herself about rats and poverty" [92]). They are linked to Dad, who is called "the Black Rat" (538). They also belong to the fantastic world of the road, in Dad's narration ("it shrunk into a big rat" [111]). Lastly, they are linked to Jeremiah, a figure of the artist in The Famished Road, through the story of the Pied Piper (cf. Cooper 96-8). 
author is visionary, endowed with powers that overcome human contingency. His is also a position of rationality, as appears in such statements: "I did not believe the story" (311) - this sentence is also the emphatic end of a chapter and comes after a narration in indirect style. With this assertion, Azaro implies that some stories are not true to life and that his will be. The importance of veracity, a notion that should be irrelevant in the realm of fiction, is also seen in the emphasis laid on the reliability of his memory, granting the reader direct access to life as it was really unfolding: "I remember the day distinctly when, on my way back from school, great crashing noises exploded over the forest" (328). The unexpected position of the adverb "distinctly" is one more way of highlighting the exactitude of the memory and its account.

Narration is posited as both a visionary gift and an account of reality as it stands, as is demonstrated by the mask contemplated by Azaro during one of his customary wanderings: "carved by an artist who has the gift to see such things and the wisdom to survive them" (283). Far from being an artefact, a deformation of human features, a disguise of the real face, the mask becomes anti-carnivalesque and is true to life itself, while the word "wisdom" goes back to the previously developed conception of the novel as the place where the reader will learn. In some passages, it is quite clear that Azaro fits that category of daring visionary artists. He becomes a translator for our sake, as when his mother asks him to polish his father's boots, while "what she really meant was: 'What has happened to your father?"' (322). Very often his intuitions are presented with all the appearances of certainty, as when he describes Jeremiah's departure: "I knew he was lying. That was when I knew we wouldn't be seeing him for a long time" (306). Shortly after such a realization, that of a highly perceptive character indeed - the photographer will not reappear any time soon except through comparisons drawn by Azaro himself - there follows an admission of powerlessness ("I couldn't make out what fantastical things he was saying") which displaces the border between the real and the esoteric, anchoring the moment firmly in reality. The end of the chapter is rather puzzling in its argumentation: "we were fondest of the photographer. And it was because of our fondness that I was sure we would see him again” (306). The second sentence shows every formal sign of a logical deduction ("it was because ... that") whereas the clue given ("our fondness"3) explains nothing. The passage mimics the logic of children, where the affect is endowed with magical qualities. Azaro's innocence and his experience mingle and should not be opposed, as they often are; their being combined accounts not only for the very specific voice in the novel; it concentrates the instability of narrative voices in one character.

Indeed, beyond being related to his status as an abiku, Azaro's insight is linked to his mere age; but abiku are necessarily children. In $A$ Time for New Dreams no less than four sections are dedicated to childhood ("On Childhood") and develop the Blakean idea according to which adulthood corresponds to a loss of understanding. This allows for a complete reconsideration of the notion of Bildungsroman, since the latter genre relies on the common assumption that experience is acquired with time - this is radically upended by Okri in this and other novels. In "On Childhood (2)" and in the direct lineage of Blake, who is quoted on the same page, Okri goes further and associates, fully counter-intuitively, childhood and art: "The child is born into an inheritance of

3. Incidentally, the etymology of "fond" has to do with silliness and derives from a verb, fonnen (to be foolish), which might share a root with both "fool" and "fun." 
all books, all the music and art and science that have been created in the perpetual pilgrimage of humanity along the dusty roads of time" (34). Art need not be acquired, as when Dad awkwardly attempts to become educated (468-9).

The novel relies on the Romantic ${ }^{4}$ topos according to which the world explicitly and quite outwardly makes sense, if one is able to hear it, as children and artists can. Voices are heard all around, often without their being traced to a distinct, or even human, source of enunciation: "the road became a river of voices," (132) "the voices followed me, voices without bodies," (196) "Soft voices sang from the bushes," which is internalised and becomes, "I listened to the many voices in me" (255; see also 70-2, $103-4,125,324,545$ among many other examples). Elsewhere, entire pages of dialogues register voices that remain anonymous (323). Much like the stories that are constantly announced and avoided in the novel (see e.g., the story of the stomach [94-5]), those voices never actually reach us and what they have to say remains a mystery. Azaro is the one who gathers their knowledge, as in the episode, one of the only ones that sketch a context for the plot, when he hears about the Independence of his country through women gathering at Madame Koto's (89-90).

I wish now to underline to what extent the limited viewpoint of a young boy is quite systematically linked to the question of mimesis and of language. Thus, he analyses physical violence with outstanding clear-sightedness (e.g., 407-8) but fails to understand the lynching photograph produced by Jeremiah (304-5). The situation is typically one in which the adults wish to hide some gruesome reality, with the photographer declaring that Azaro is too young (a declaration echoed by Dad's "You're too young to hear all this," 305) and wishing "to change the subject," with an ironical ${ }^{5}$ hesitation on the latter word, which could also be understood as the subject of the image, not the conversation. Azaro's comment on the dead man's face is interesting: "strange, almost familiar" (304). He of course recognises someone who partly descends from his own people since American slaves were mostly captured in what became Nigeria, but also from white slave-owners, so that this man looks and does not look like a brother. ${ }^{6}$ Similarly, Azaro turns out to be an inapt reader: "Most of what I read made no sense to me" (468-9). These words are taken from the passage where Dad becomes obsessed with books but, illiterate as he is, asks Azaro to read them to him. One might be tempted to take such distrust of literature as a distancing from the literature of Empire, one which had mapped out foreign lands with prejudice and which also included children's literature, as is the case with R. L. Stevenson, Rudyard Kipling or Rider Haggard (see Sévry) - or else a denunciation of colonial syllabi that comprised the classics but no text written outside Europe. In any case, numerous are the instances when Azaro confesses his hermeneutic limitations: "Then they showed me images which I couldn't understand" (8). One might wonder whether the modal verb ("could") designates an ontological impossibility or if the preterit is merely the effect of tense agreement, thus meaning that Azaro was

4. This notion can be found in Blake's poetry but also in Keats' Odes, for instance, especially so in "Ode to a Nightingale."

5. Irony is the device that relies on a distance (it is the etymology of the word) between what is said or written, and what the interlocutor or reader is supposed to understand. Understanding is thus yet another form of in-betweenness in the novel, where Azaro must sometimes be followed in his understanding of the world, but where he can also fail to see things for what they are.

6. On the "slave-scape" which brings together Africa and America along the "routes" of the slave trade, see Paul Gilroy's by now canonical Black. Atlantic. On the collusion of strangeness and familiarity in The Famished Road, see Raynaud 342 . 
not able, at the time, to decipher those pictures. Still, an inability to understand recurs in the novel, notably so in the episode when Azaro first encounters the prostitutes at Madame Koto's bar. They are not called prostitutes at that moment because an internal focalisation on the young Azaro prevents him from accurately analysing the situation. He uses the same ambiguous past tense twice and writes: "their mouths [...] spoke to me of an infernal unhappiness which I couldn't understand. [...] she began pulling my arm, pestering me with words I couldn't understand" (315). As in the example of the rats' definitive pronouncement about the world, what must and cannot be understood is already a linguistic formulation: "mouths," "spoke," "words." In addition to this semantic inadequacy, Azaro's inexperience extends to the music, whose source remains mysterious to him.

More generally Azaro is betrayed in his testimony by some discrete and discreet textual marks. He sometimes declares, after having omitted to mention that he had fallen asleep, that he wakes up suddenly (e.g. 127), thus casting a retrospectively cautious light on what has just been read. Alternatively, he gets drunk $(54,101-2)$, and it is difficult for the reader to know exactly when his narration becomes dubitable, if not untrustworthy altogether. Yet some passages, such as the one describing the malaria fit and the hunger strike, reveal by contrast that during the rest of the narration, Azaro must be sound in body and in mind. I contend that the effect produced is also one which makes the reader understand that the world makes no sense, because things have gone seriously awry under the failing responsibility of men. The narrator's unreliability, which has been read by some critics as the sign that borders are porous in the ontology of the novel, ${ }^{7}$ would thus be a political statement. It fully pertains to the role with which fiction is endowed, one which precisely negates fictitiousness in order better to reach reality. Indeed, the commitment of the novel is obvious, as Quayson has pointed out: "Okri's work articulates a particular perception of events in post-colonial Nigeria that brings the literary tradition into a direct engagement with the ambit of the socio-political while remaining steadfastly in the realm of the mythopoeic" (121).

I wish now to discuss the realist stance that lies at the core of the novel's perspective. If Azaro's testimony oscillates between reliability and unreliability, there remains an insistence on his part on the fact that there are things he understands, and others he does not. The enterprise thus appears as one of explanation, as is reaffirmed in the quote that opens Songs of Enchantment, a line taken from Virgil's Georgics: "Blessed are those who know the causes of things." His conception of his tale is one in which the world must be taken in, a far cry from the outright severance from reality ${ }^{8}$ that characterises most postmodern fiction and turns it into a purely intellectual game. Azaro states that according to the turtle, "no story could ever be finished" (550): indeed the structure of his text springs from life itself, something that has no beginning or end. Let us remark that in this quote, the turtle is described as "a wandering griot," yet another avatar of the narrator. Writing is then envisaged as a going back and forth, from life to the page, and back again. In the following account of the road seen with Dad: "I looked at the

7. E.g., "this unreliability is a key part of the narrative strategy, which is to render uncertain the reality-esoteric axis that a reader may try to implement to make sense of his or her reading" (Warnes 139).

8. I take this tricky notion here as a whole, regardless of the systematically made distinction, about the novel, between an everyday life sort of reality and that of the fantastic spirit-world. What interests me here is the opposition between any sort of extra-textual reality and the novel itself. 
road with new eyes. It was short and marvellous. It was a work of art, a shrine almost, beautiful beyond description," (379) the last phrase suggests that the world and the text which could describe it are ultimately incompatible. One could counterpose such an attitude to postmodern texts, where it is traditionally clear that the world and the text are one and the same thing; one could mention Rushdie's Midnight's Children (1981) or Derek Walcott's Omeros (1990), two other postcolonial texts that were published a few years earlier and where the author stages himself writing a book that bears the same title as the one we are reading. Things are further complicated by the fact that reality, in The Famished Road, tends to shed its conventional attributes in order to imitate fiction, as in: "The world is just beginning,' Mum said" (554) - the fact that such a pronouncement comes at the end of the novel shows to what extent the beginning and the end may be interchangeable here. As a matter of fact, the turtle's declaration that no story can be finished ties up with another book, in Ade's words: "The Koran says nothing is ever finished" (547).

Story-telling allows Okri to further define the role of the narrator in the novel. I shall not go back to its often abortive dimension (see Guignery 124) but to the source of those stories which teem in the text. Stories are never invented by Azaro, who merely transcribes them. He is indebted to Mum and Dad, but also to spirits (378-9), to Madame Koto and Ade. This draws a portrait of the writer as scribe, setting to paper the evanescence of words, without interpretation and without invention. What is interesting, however, is the absence of idiolects in this novel - the polyglossia allowed by the genre of the novel is thus severely amputated. In Dickens' novels for example, names can be skipped during dialogues, so easily can characters be recognized through their speech. The Victorian novelist rightly occupies some pages in "Discourse in the Novel" where Bakhtin scrutinises the effects of language as taken "not as a system of abstract grammatical categories, but rather [...] conceived as ideologically saturated, a worldview, even a concrete opinion" (489-90). Instead, the style is uniform in The Famished Road, a feature that becomes very striking on the occasion of the only exception to the rule, "What kind of question is dat?" (367). Nowhere else do characters have a distinct voice, to borrow the expression chosen by Gates to apply Bakhtin's findings to Black American speech (xix-xxii).

The role of the narrator and of the artist at large is here that of an objective witness (or of spy even, see 490). Azaro and Jeremiah are eyewitnesses, which partly accounts for the foregrounding of vision and the sense of sight throughout the novel. Like the gnomic pronouncements, some sentences seem to escape the realm of fictional representation to hold on to the barest reality, such as the passage where Azaro describes the poverty and dereliction on the streets around him:

Everywhere there was the crudity of wounds, the stark huts, the rusted zinc abodes, the rubbish in the streets, children in rags, the little girls naked on the sand playing with crushed tin-cans, the little boys jumping about uncircumcised, making machine-gun noises, the air vibrating with poisonous heat and evaporating water from the filthy gutters. The sun bared the reality of our lives and everything was so harsh it was a mystery that we could understand and care for one another or for anything at all. (189)

The limited presence of verbs and the simplicity of syntax in general in this passage testify to the foregrounding of the referential dimension. Even though The Famished Road departs from the social realism of Ben Okri's two previous novels, Flowers and 
Shadows (1980) and The Landscapes Within (1981), such an awareness remains very much in sight in Azaro's rendering of the run-down conditions around him, of "mortgaged futures" and "delayed destinies" (568). Repeatedly and obstinately, Jeremiah appears as a witness, collecting proof of the oppression against the poor in the ghetto, notably so when people become sick after drinking the rotten milk distributed by the ruthless Party of the Rich (155-6). It is precisely his role as a witness that will provoke his persecution and eventual disappearance.

Still, the passages that stage Jeremiah also suggest the striking absence of a single perspective, as seen in his first appearance in the novel (54-5). In order to take a photograph of the first party thrown by Dad, he distorts bodies in a way which is reminiscent of Cubism, so that one seems to see the same body from various viewpoints: "He made Dad twist his legs, made Mum hold her neck at an awkward angle.” Further on, Azaro writes, "[he made] us contort our heads." This reasserts the impossibility of producing an accurate representation, not because the scene is too chaotic but because the human being may not be truthfully rendered by any sort of art, visual or otherwise. The cubist diffraction of perspective is also the result of Azaro's position in this text, as well as in the whole novel. Indeed, unlike an Ishmael or a Nick Carraway, who may be intra-diegetic narrators but remain minor protagonists in the plot, Azaro is both the main character in the novel and its narrator. An additional complication in the diegetic structure is the immeasurable gap between the child and the older narrator. Such a complex incongruity between the narrated character and the narrator is suggested in this particular passage by the strange shift that occurs when Jeremiah starts posing for his own lens, an obvious preposterousness: "the photographer proceeded to embark on his own set of dramatic poses" (55). This draws a parallel with Azaro, both the subject and the object in The Famished Road and one of the constant interrogations at the core of this long novel, not to mention its two sequels. Another contradiction in perspectives is to be found in the accumulation of arts that are presented in this very passage, some (music and dance) belonging to the Dionysian ${ }^{9}$ practices and others (writing, photography), to the Apollonian, to borrow concepts defined by Nietzsche. It actually appears that the narrator is after all quite reliable in that he attempts to create a certain amount of order, as is seen by the two conjunctions "while," which open each of the two long paragraphs respectively on pages 54 and 55. The narrator clearly distances himself from the Dionysian frenzy and portrays the scene with what can actually be described as apparent neutrality. His text could be read as a testimony or even as a satire, a genre that implies a rational perspective. Indeed, when he describes the squabbling over "the most visible positions" (55) or the coquettishness of women, it is certainly from the point of view of a wiser outsider, regardless of his age. In addition to all this, numerous are the passages (e.g., 78-9, 281-2) where the description of an encounter made by Azaro multiplies the clues that point to the figure of the double, further diffracting perspective. As the spirit suggests, "When you can see everything from every imaginable point of view you might begin to understand" (376).

Still, most of the novel can be described as lyrical, that is to say that it is a first person narration registering the impressions of an I-eye. There are metaphors that unmistakably point to an individual subjectivity: “as if a hurricane had passed and hadn't

9. Dionysus is often compared to the Yoruba divinity of Ogun, as in Soyinka: "I had [...] recognized in the Greek deity Dionysus a long-lost sibling of my personal demiurge, Ogun" (112). 
been noticed" (130). In the novel, linguistic markers attest everywhere to the prism of Azaro's gaze and interpretation. There are modal verbs (e.g., "which must have scared the poor bird" [318]) and adverbs ("slightly crazy" [349]); there are verbs retracing impressions ("to sound," "to seem") and comparisons that do the same ("it could have been the end of the world" [329]). A correlative to this lyricism combined with realism, a prevailing opposition between the inside and the outside, but also the self and the community, is foregrounded on all levels in The Famished Road. The contraposition is taken to its extreme with Azaro himself becoming an outsider for himself, as in such moments: "to my shock I saw myself approaching" (79) or "inside me there were wide open spaces" (194-6). Such an oscillation both forecloses and raises the issue of the satire, a genre based on a clear-cut distinction between an individual viewpoint and that of a group. I shall not dwell on the concept of satire but wish briefly to quote Frye to show to what extent his definition rings true in the ear of Okri's reader: "Satire demands at least a token fantasy, a content which the reader recognizes as grotesque, and at least an implicit moral standard" (224). There remains an opposition in the distribution of space between the inside and the outside which recalls Okri's position as an author, both "inside and outside of realism" (qtd. in Guignery 101).

As a result, The Famished Road self-reflexively presents itself as a jumble, a bungle, a failure of sorts. One may thus read the reduction of the last section to one single book and one sole chapter: the movement is reductive, tentative, abortive. As for the chapter immediately preceding that last book, it has prepared the reader for such disappointment through an accumulation of reasons for the narrative to fall through, even while an anaphoric "things" suggests the inability of the narrator to find the right word: "Things that are not ready $[\ldots]$ things that are not resolved, things bound up with failure" (558). This novel drastically shuns the device through which the ending reveals clues demanding a re-reading of the whole text: The Famished Road concludes its hundreds of pages with a confession of inadequacy, reduced to "the recurrence of things unresolved" (207). Fiction turns out to be irrelevant due to the poor state of the corrupt, poverty-stricken, unfair world, one which men have not shaped as they should have and where "nothing happens," as is often repeated and deplored by Azaro (e.g., $27,309)$; in this last pronouncement the absence of any positive change and the impossibility for fiction to be launched are both expressed. For all that, the discourse in The Famished Road is not pessimistic, a far-right lament about modernity. Instead, it calls for change with vigour and conviction.

My last point is that the puzzling oscillations in the authority of Azaro are inscribed within the plot of the novel in the relationship between the young boy and his father. It is possible to see the Bildungsroman as actually that of Dad, whose millennial prophecy closes the novel and who becomes the champion of the poor, the beggars, the havenots. His changes are visible in the following accumulation of comparative structures: "his spirit had sharpened, his despair was deeper, he was a bigger man with a bigger madness" (570) and he is declared on the last page to have grown "heavier," in a strange parallelism with Madame Koto's evil weight. Critics have noticed that Dad's three symbolical deaths liken him very much to an abiku (but also to Lazarus, or Azaro: "Dad was sitting up on the bed like Lazarus" [554]) and blur the distinction between father and son. Azaro wonders if he is not reborn as his father (567) right before becoming himself the father of an abiku child, his country. In any case, the "authority" embodied 
by Dad is sometimes bestowed on his narrating son, sometimes confiscated. An illustration of such a conundrum may be found in one of the very few books mentioned in The Famished Road, one that is precisely read to Dad by Azaro rather than the other way round: "I [...] read to him again from Homer's Odyssey" (489). The Odyssey after all tells of a double pilgrimage, that of Odysseus, who is trying to go back home, but also that of Telemachus, who is looking for his father and then comes back to help him in his fight against the suitors. The confusion is furthered through the character of Helen, one of the beggar-girls but also the original quest object of Odysseus and his companions: Helen is Dad's protégée, but also Azaro's friend. This might be an ironic twist of the passage in Book Four of The Odyssey where Helen, back in Sparta, tells Telemachus how she recalls Odysseus dressing as a beggar to enter Troy stealthily at night. The authority embodied by Azaro, as a narrator, is shared with Dad whose quest looms large on the horizon of the novel's puzzling and volatile plot (on such a problematic association see e.g., Ogunsanwo 41 and its refutation in Deandrea 59).

The diffraction of authority is to be seen again at the end of the novel, one which also picks up on my liminal interrogation around that last sentence whose ambiguous enunciation is pointed out by Claudine Raynaud:

The last sentence could be uttered by an omniscient narrator who conflates the identities of Azaro as "I" narrator and Dad's as speaker of impassioned tirades: "A dream can be the highest point of a life" (574). Who is speaking? Dad's earlier exhortation about "mak[ing] the dream real" (571) gives the option of replacing this last utterance within his or Azaro's own "lifespan," folding back the novel on to the realm of the real. The preterit that governs the narrative is abandoned for the modality of a general assertion, an aphorism. It could also be a final intrusion of the author. However, self-enclosed, it has no attributable speaker and cannot provide an apt ending to the text that is left "hanging." (336-7)

"A dream can be the highest point of a life": such an open-ended conclusion is recycled and reshuffled in various places in the following two novels in the trilogy, not least in this passage from Infinite Riches, a dialogue with a dead Ade:

"Why do we lose the highest points in our lives?" I asked.

"To go either higher, or lower."

"Why do we lose the best dreams of our lives?"

"Because we forget."

"How can we stop forgetting?"

"By renewing ourselves."

"How?"

"By becoming a child again every seven years."

"Do we always have to lose our best dreams?"

"Yes." (389-90)

The strange certainty at the end of The Famished Road, which had been seriously imperilled by the indeterminate enunciation, morphs into a general inability to understand. The series of questions in this last quote may suggest that if fiction is denounced as irrelevant in its authority and consequently short-lived validity, it still helps to formulate the most adequate interrogations. What and how to wonder (and wander), here is probably one of the main focuses of the novel. 


\section{Works Cited}

Achebe, Chinua. "The Novelist as Teacher." Hopes and Impediments: Selected Essays, 1965-1987. Oxford: Heinemann, 1988. 27-30.

Bakhtin, M.M. The Dialogic Imagination: Four Essays. Trans. Caryl Emerson and Michael Holquist. Ed. Michael Holquist. 1975. Austin: U of Texas P, 2000.

Cooper, Brenda. Magical Realism in West African Fiction, Seeing with a Third Eye. London: Routledge, 1998. FrYe, Northrop. Anatomy of Criticism. Princeton: Princeton UP, 1957.

Gates, Henry Louis. The Signifying Monkey: A Theory of African-American Literary Criticism. New York: Oxford UP, 1988.

Gilroy, Paul. The Black Atlantic: Modernity and Double Consciousness. 1993. London: Verso, 2002.

GuignerY, Vanessa. Seeing and Being: Ben Okri's The Famished Road. Paris: PUF-CNED, 2012.

Neweld, Stephanie. West African Literatures. Oxford: OUP, 2006.

Ogundanwo, Olatubosun. "Intertextuality and Postcolonial Literature in Ben Okri's The Famished Road." Research in African Literatures 26.1 (1995): 40-52.

Okri, Ben. The Famished Road. 1991. London: Vintage, 2003.

—. Songs of Enchantment. 1993. London: Vintage, 1994.

—. Infinite Riches. 1998. London: Vintage, 2009.

—. A Time for New Dreams. London: Rider, 2011.

Quayson, Ato. Strategic Transformations in Nigerian Writing. Bloomington \& Indianapolis, James Currey: Indiana UP, 1997.

Raynaud, Claudine. "The Text as Riddle and Death's Many Ways: Ben Okri's The Famished Road." Études anglaises 65 (2012): 331-46.

SÉVRY, Jean. "Rider Haggard: A Literature for Children or a Childish Africa?" Commonwealth 15.1 (Fall 1992): 1-11.

SoyINKA, Wole. You Must Set Forth at Dawn. New York: Random House, 2006.

Warnes, Christopher. Magic Realism and the Postcolonial Novel: Between Faith and Irreverence. Basingstoke: Palgrave MacMillan, 2009. 